\title{
A Study on the Mothers of Roma Children Who Are a Risk Group
}

\author{
Maide Orçan ${ }^{1 *}$, Canan Yıldız Çiçekler ${ }^{2}$, Ramazan $\mathrm{Ar}^{3}$ \\ ${ }^{I}$ Muğla Sitkı Koçman University, Turkey \\ ${ }^{2}$ Selçuk University, Turkey \\ ${ }^{3}$ Selçuk University, Turkey \\ *E-mail: maideorcan@gmail.com
}

\begin{abstract}
This study aims to define Roma mothers' views regarding their children's education and their tendency towards crime. The study is based on an illustrative case study method. The participants of this study are mothers of Roma children between the ages of 4 and 6 who live in Konya, Turkey - more specifically in the Yenimahalle neighborhood in the town of Karatay - and who do not attend any preschool programs. As a data collection tool, a questionnaire prepared by the researchers is employed, while in data analysis, descriptive analysis is used. The Roma mothers articulated that they want their children to have education and jobs; that they do not want their children to suffer in the same way they did; that the Roma culture prevents children's education and therefore the mothers prefer to send their children to private schools, boarding schools or to schools far away from their neighborhoods by taking school buses; that they want their children to be judges, lawyers, nurses and teachers. The mothers stated that they meet the basic needs of their children; that they watch TV together and/or do housework together with their children. They also said that when their children commit a crime, they beat their children; they get angry with them and scold and/or complain to their fathers. They finally added that they can take measures for the children's not committing a crime by talking to the children or by scolding them. Additionally, Roma mothers state that by taking the case to the fathers they can prevent their children from committing crimes.
\end{abstract}

Keywords: Roma mothers, Roma children, preschool period, education and crime

\section{Introduction}

There are no certain facts and figures with regards to the Roma living in Turkey. Minority groups in the Turkish Republic are not defined according to codes, and therefore every individual who lives within the Turkish territories is a Turkish citizen (UNICEF, 2012). In Turkish dictionaries, a Roma person is defined as a dark-skinned, stingy, impudent, unashamed and noisy person. According to Gökçen and Öney (2008), there are prejudices in the society, and on the lightest side, the majority of the people consider the Roma as being capricious and carefree people who live their lives more superficially and daily within the "dans-music-flower" triangle; however some people who are more contumelious believe that the Roma people are criminals and are immoral. On the other hand, since the Roma do not oppose to the nationalist discourses and demands, they are not considered as a problematic minority group from the state's point of view. While the Roma are being discriminated on the one hand, on the 
other hand, they are perceived as the modal group - "cheerful and unproblematic people"-for the other minority groups which are having conflicts with the state (Koptekin, 2013).

It is known that the majority of Roma people living in Turkey do not accept the Romaness because of the fact that the Roma people are despised, alienated and belittled in the society (Özkan, 2013). These issues have negative reflections both on societal and on individual levels (UNICEF, 2009). Moreover, this situation affects the Roma children negatively by pushing them towards the risk group. The children under risk can be grouped under four categories: the working children, street urchins, children who are pushed towards crime and children who are abused. An analysis of these groups reveals that actually these groups are not independent from each other; on the contrary they are all intertangled (MEB, 2013). The notion of children under risk not only includes children who commit a crime but also comprises children who are likely to tend towards crime (UNICEF, 2009). Therefore, the Roma children need to be considered as a risk group.

In order to prevent Roma children from tending towards crime, it is very important to keep these children within a school system. However, current school systems are not sufficient to meet the educational needs of the Roma children (Smith, 1997; Cigez and Lopez, 1999). It is a known fact that most of the Roma children who register to schools do not continue schools, and they drop out. With regards to the reasons why primary school students drop out from schools, five major factors can be pointed out: demographic factors such as low socioeconomic statues and poverty; family-related factors like distrust towards school, parents' education level, the number of children in the family, singleparent families, extended families, the case that the parent is also a drop-out, the case that the parent is in prison; student-related factors such as lack of student motivation, school adjustment problems, academic failure, class repetititon, external focus of control, not completing tasks, discipline problems, attendance problems, drug-alchocol use or addiction; education system related factors like low participation of teachers, limited financial and human resources as well as social factors (McDonald, 1999; Kyuchukov, 2000; Aspy, Oman, Vesely, McLeroy, Rodine and Mershall, 2004; Özdemir, Erkan, Karip, Sezgin and Şirin, 2010; Enache, 2012; Bedmar and Leon, 2012).

The number of academic studies on the Roma people is very few, and it is also striking that there are not enough resources and research projects especially with regards to the Roma children in Turkey. Education is one of the most important issues of a country, and every individual in a society has the right and responsibility to get education. The researchers stress the importance of the Roma children's getting education and then having professions, raising their life standards and adjusting to the social life. Determining what Roma mothers think about their children's education and their tendency towards crime and what the mothers' expectations are is very important. It is believed that this study will be of importance as it will lead other (more comprehensive) studies in the field.

Today, the Roma people living in Turkey are dispersed in different geographies. They mostly live in the neighborhoods known as "crime zones" in big cities (Hacihüsrev in Istanbul, Yenidoğan in Ankara, Kadifekale in İzmir, Yenimahalle in Konya) (Erdeniz, 2005). This study is conducted in Yenimahalle neighborhood in Konya. Looking at the data and statistical information collected from the Juvenile Department at the Konya Provincial Security Directorate, Directorate of National Education, primary shool administrators and teachers in Yenimahalle, the researchers found out that the Roma children's school attendance and participation rate is very low, which is the most influencial factor in children's tending towards crime. On this basis, this study aims to determine the views of the Rome mothers in the Yenimahalle neighborhood in Konya regarding their children's education as well as their tendency towards crime, and finally offer some solutions.

\section{Target Population of the Study}

According to a study conducted by the Juvenile Department at the Konya Provincial Security Directorate (2005), it is observed that instead of attending school, children of the Roma families in Konya sell tissue papers, weigh people or clean car-windshields in the streets, which can be considered 
as begging in the streets. It is determined that $\% 55$ of the working children are between the ages of 12 and $15 ; \% 24$ of them are between the ages 0 and 11; and \% 21 of them are between the ages of 16 and 18. It is seen that the children who vends in the streets have education problems. $\% 10$ of the children who vends in the streets in Konya have never attended school; \% 2 of them are literate; $\% 5$ of them are school dropouts; and only $\% 2$ of the children are primary school graduates, while $\% 8$ of them are high school students. \% 73 of the school-age Roma children continues school. On the other hand, academic achievement level of the children who attend school is very low. While $\% 94$ of the children who vend in the streets has not got involved in any crime, \% 4 has committed crime. Children who work in the streets are open to all sorts of danger and are at the risk of committing crime and being a victim of crime. \%77 of children who beg in the streets is registered in Konya. However, it is observed that, mostly it is the children from subculture, from "Gypsy/Roma" families who beg in the streets.

In the neighborhoods such as Yenimahalle, Doganlar and Cimenlik where mostly Roma families which moved from rural culture to urban culture reside, it is seen that children beg in the streets. It is observed that \% 51of the beggar children are at the age of 06-11; \% 41of them are at the age of $12-15$, and $\% 9$ of them are at the age of $16-18 . \% 54$ of the beggar children is illiterate; $\% 9$ is primary school dropouts while another $\% 9$ are literate. In other words, $\% 72$ of the children have education problem and the remaining $\% 28$ are primary school students who have problems with their courses. \% 93 of the beggar children have not involved in any crime, and \% 7 of the children have committed crime. As for the place of registry of the drug addicted children in Konya, \% 26 of the children are registered in Karatay town center; \%18 of them are registered in Çumra, and \%16 of them are registered in Meram town center. $\% 50$ of the drug addicted children live in Karatay town center. It is observed that in the city of Konya, substance use age starts from 13 and gets more intense at the age of 16-18. Roma children who use substance also have education problems. According to the records of the Konya Provincial Security Directorate, \% 42 of the drug addicted Roma children are primary school dropouts; $\% 37$ of them are primary school graduates; $\% 17$ of them are primary school students and $\%$ 4 of them are literate. According to the records of the Juvenile Department at the Konya Provincial Security Directorate, \% 61 of the drug addicted Roma children, in other words, 33 children have committed crime. From this information, we observe that substance use is a serious threat that pushes children towards crime (http://www.konya.pol.tr).

\section{Method}

This study has two major aims. We seek answers to the following questions:

a. What do Roma mothers think about their children's education?

b. What do Roma mothers think about their children's tendency towards crime and their children's crime situations?

\section{The Research Design}

This study has been conducted within the framework of a case study design, which is one of the qualitative research designs. Illustrative case studies methods have been employed in this study (Yıldırım and Şimşek, 2006).

\section{The Study Group}

This study is conducted in the Yenimahalle neighborhood in the town of Karatay, in Konya. The reason why this particular neighborhood was selected for the study is because it is fully inhabited by the Roma families. The study is based on interviews done with the Roma mothers who were born in Konya and still live in the city. The target population of the study consists of mothers of Roma children who are in 4-6 age group and who live in Konya and do not attend school. 30 mothers with children between the 
ages of 4 and 6 were randomly selected for this study in accordance with the data collected from neighborhood executive officer. The Roma mothers' age differs between 18 and 45.17 of the mothers in the study group are at the 26-35 age group; 10 of them are at the 21-25 age group; 2 of them are at the 36-45 age group, and 1 of the mothers is at the 15-20 age group. The level of income for 12 Roma families is $300 \mathrm{TL}$ and more, and for 9 families, it ranges between 0-50 TL. While 4 families' income level is $50-100 \mathrm{TL}$, the level of income for another 2 families is between 100-150 TL. There is 1 family with the income level of 150-200 TL, another family with the income level of 200-250TL and, finally, 1 family with 250-300 TL income level. It is also considered that the Roma mothers might purposefully show their income levels low, hoping that they might get some assistance. Among the Roma mothers, 28 of them do not have any fixed income; 2 mothers do have fixed incomes. While 21 of the Roma mothers do not work, 4 of them sell tissue papers, 3 of them do house cleaning and 2 of them are peddlers. 20 of the Roma mothers are illiterate, while 6 of them are literate and 4 of them are primary school graduates. 23 of the Roma mothers had their children between the ages of 15-20, and 7 of them gave birth between the ages of 21 and 25.16 of the Roma mothers did arranged marriages, and 14 of them eloped and got married. All of the Roma mothers have civil marriages. 27 of them are together with their husbands, while 1 is divorced. 2 of the Roma mothers' husbands are in prison. 15 of the Roma mothers have two children; 6 of the mothers have six children; 4 of the mothers have 4 children; 3 of the mothers have three children; 1 of the mothers have five children and 1 of the mothers has one child.

\section{Data Collection and Evaluation}

In this study, as a data collection tool, a questionnaire was conducted with the Roma mothers who have 4-6 age group children not attending school. The questionnaire includes four open ended questions about the children's future education and two open-ended questions regarding children's tendency towards crime. To have the internal validity of the questionnaire, we consulted with three experts. Open-ended questions in the questionnaire are prepared to collect data about the two sub-problems of the study. Moreover, the questionnaire includes some close-ended questions to obtain information about the participants' demographic characteristics. Since almost all of the mothers who participated in this study are illiterate, the researchers conducted the questionnaire with the mothers on a face-to-face basis. The data is from 2009.

\section{Data Analysis}

The views of the Roma mothers regarding their children's education are grouped under five major titles, while their views on the children's tendency towards crime are listed under two titles. Information about children's school attendance is obtained from the Primary School principal in the neighborhood. Descriptive analysis is employed in the data analysis.

\section{Findings and Discussion}

This section presents Roma mothers' perspectives on their children's education and tendency to violance.

\section{A. Views of the Roma mothers regarding their children's education}

\section{Factors restraining Roma children's education:}

Mothers who participated in the research study want their children to have education and they enroll their children at schools at the beginning of the school year. However, attendance sheets taken from schools in that area show that children stop to attend classes in the upcoming days. The main reason of Roma children's attendance problem is that they are forced to work starting from very early ages. Roma 
families do not allow their children to go to school, and the ones who send their children to school are just aiming to make their children learn to read and write. There are two main reasons for that; first reason is economic insufficiency (Akgün, 2004; Akkan, Deniz and Ertan 2011; Uğurlu, 2013) and second reason is the despair for their future. Although families think that their children should have education, they do not believe that their children can go further with a vocational training after elementary school and become respectful people with a recognized occupation. This statement is supported in similar researches (Erdeniz, 2005).

Moreover, the fact that the discriminatory and exclusionist perception and language which are prevalent in the society are also employed in the schools yield to the Roma children's getting estranged from the school. In addition to this, due to early-age marriages, Roma children also leave school (Akkan, Deniz and Ertan 2011). In a study by Uğurlu (2013), it is stated that the children at the schoolage only study until the end of the primary school because of the compulsory education requirement. The study also tells us that only five of the families' children have attended high school, and four of these children are males. Furthermore, it is also stated that girls start to get married at the age of 14-15, and some of the girls are even asked to get married right after primary school and, therefore, not allowed to go to school. In a study by Akkan, Deniz and Ertan (2011), it is argued that in Yenimahalle neighborhood in Konya where the Roma families live mostly, families do not register their children to school also because of the fact that they take care of civil registration of their children late, and so their children's actual age is much older than the school-age.

Attendance problems of Roma children is also quite prevalent in CEE countries (Albania, Bosnia Herzegovina, Bulgaria, Croatia, Czech Republic, Estonia, Litvania, Macedonia, Poland, Romaa, Slovakia, Slovenia, Yugoslavia). Extra-scholastic programs which are aiming to integrate Roma children to education system are failed to develop in those countries. Most of the children who drop out school in CEE countries are Roma children. It is determined that the main reasons of high drop-out rate of Roma children are the financial status of Roma families and inflexibility of the education system (Kyuchukov, 2000). Researches show that Roma children's attendance to school is in a very low level in all over Europe. Although results reveal that half of the Roma children in Europe, who are at schhol age, attend school regularly; a very little number of them attend practically. These might be because the Roma do not think it is worth to go to school and do not continue their formal education. They consider schooling a hard and painful process; and they think that it does not equip the person enough for being successful in life. In addition to that, schooling is perceived as an impractical and ineffective for real life, because school restrains Roma children's contribution to family economy (Cozma, Cucos and Momanu, 2000).

In a study by Bayraktar Akkaya (2011), the problems of the Roma with regards to education was revealed. Most of the Roma participated in the study could either study until the fifth grade or never attended any school. They all gave similar answers to the question why they did not attend school. Some of the most striking answers are: "My father knew nothing but gambling, and I spent my days out in the streets hungry; how I was supposed to go to school" or "I could not study because of poverty". To the question whether or not language problem affected their education, they all answered that they do not know any other language than Turkish and stressed that the financial incapability is the major reason behind their lack of education. However, today their own children also do not attend school regularly. When they are asked why this is that way, almost all parents stated that "Our children do not love school and studying. We would, indeed want our children to study and get a proper job". Şükran, one of the women participated in the study, complained about her son's indifference towards school while her son, meanwhile, stated that "I could not study; if I could, I would like to be a captain" and then kept silent. In this meeting, while the mother blamed her son for his lack of education, the son pointed to the fact that he is not in a position to make the decisions that will affect his life.

Moreover, it can be stated that the Roma cannot benefit from the city's cultural and social life offerings since they mostly live in the suburban neighborhoods, outside the city. Also, recently, the 
Roma families have been affected by the local governments' urban transformation projects as their settlements are under the threat of demolition. The Roma is the group which has the loosest relationship with education. The drop-out and non-attendance rates are the highest amongst the Roma children. It is observed that some of the Roma childeren who are third or fourth graders still cannot read and write. Due to the lack of comprehensive welfare policies that will solve the education problem of Roma children, children usually work with their parents and they drift away from schools. (Akkan, Deniz and Ertan, 2011). As seen in the aforementioned studies, the Roma children do not continue their education for various reasons.

\section{Views of Roma mothers' on why they want their children to have education:}

When we look at the reasons why Roma mothers want their children to have education, we see that 12 of the mothers note that "they want their children to have an occupation", 10 of the mothers note that "they do not want their children to suffer as they have had", and 8 of the mothers note that "they do not want their children to become uneducated (unable to solve their problems because of lacking knowledge)". In the research study, Roma mothers stated that they want their children to have education because they do not want their children to become uneducated and suffer as they have had. They want their daughters to have an occupation so as not to become financially attached to their future husbands; and they want their sons to get educated for being able to have a regular job and gain financial indepence and afford their future families. Roma mothers also emphasize that they do not want their children to stay uneducated in their neighborhood, and tend towards crime. Two of the mothers explain the reason why they want their children to go to school as follows:

“We got married without our parents' permission when we were too young. We were very poor. I gave birth to six children, my husband was sent to jail, I, with my six children, spent very hard times when he was in prison. If I had gone to school, I could have bought anything to my chidren, I would not have been in need of others' help when my husband was in prison. I want to send my children to school, particularly my daughters, because I don't want them to suffer as I have had. (26)"

"Since I am illiterate I don't know which bus to take when I go outside for shopping or for going to hospita, and I feel anxious about getting a wrong bus and going to a wrong, unknown place. If I could read and write, I would have gone to anywhere easily. Being uneducated is very difficult, you understand nothing from writings. We couldn't go to school but we want our children to have education. (7)"

\section{3.a. Vievs of the Roma mothers on which conditions they want their children to have education in case financial opportunity is provided:}

The children of the Roma families have difficulties with realizing themselves since they both cannot meet their primary needs as a result of poverty and they are disciriminated in the society and labelled as "gypsies", "noisemakers" and "thieves". In this case, it is seen that the Roma families make their decisions about their children based on learned desperateness. When the Roma families raise their children, they do not get out of the Roma neighborhoods, and they also send their children to schools where mostly the children from the same culture study (Suntekin, 2008). As stated in the study by Akkan, Deniz and Ertan (2011), the first phenomenon that can be observed in the Roma neighborhoods is the low education level and the low number of schools available. It is observed that within their society the Roma do not value education, and, therefore, children's education is not a matter of concern. Suntekin (2008) highlights the point that the Roma children repeat their classes more than other children, and they also start school at a later age. Although this case demonstrates that the Roma 
children are registered to schools, it also showcases how the society underrates schooling. When we look at what Roma mothers think about what kind of education they wish for their children in case the necessary financial opportunity is provided, we see that 14 of the mothers state "they want to send their children to a boarding school", 12 of the mothers state "they want their children to go to a school away from where they live, and they also want them to go to school by a school bus", and 4 of the mothers state that "they want to send their children to a private school". Roma people tend to settle collectively in some particular districts of a city; therefore, it can be stated that Roma children mostly gather in some particular schools and this enable them to carry/transfer their culture to school. Roma children generally tend to lead astray one another and skip classes.

Mothers also state that their children have attendance problems. In interviews, mothers noted that children who skip classes and do not attend school mostly affect other children negatively and make them move away from school. Roma mothers are aware of the fact that places where they live are not suitable for education, and for this reason they emphasized that they want their children to go to school in some other place away from where they live. 3 Roma mothers explain the reason why they want their children to go to school in some other place away from where they live as follows:

"Children don't have education in our neighborhood. It is because they don't go to school. It is more like a custom in this neighborhood. We really want them to go to school, we enroll them to schools but they don't attend classes. Unless our neighbor turns upside down, this situation won't change. This is why I would send my children to a boarding school or a school away from where we live if I had the opportunity. I would buy whatever they need as long as they go to school. (12)"

"I really want my child to $g$ oto school but children in our neighborhood not only skip school but also prevent other children from going to school. That's why I don't want ot send my child to a school in this neighborhood. My child won't have an education if s/he goes to a school in our neighborhood. (4)"

"If I had the opportunity, I would like to send my child to a private school. I would also like to send my child to school by the school bus; thus s/he stays away from other children in the neighborhood. (16)".

\section{3.b. Teachers' situation in Roma neighborhoods:}

In a number of interviews regarding children's education and attendance to school, teachers and administrative staff who work at primary schools in the Roma neighborhood stated that even though teachers are appointed to the schools most of them try different ways so as not to work at those schools, since they know the situation of the children and schools. Administrative staff states that teachers consider these schools as "exile". A number of teachers mention that Roma children are different form other children in terms of their life syle and attitutes/behaviours; and they take bad behaviours as example from their environment (Erdeniz, 2005).

In a research by Kyuchukov (2000) educational status of Roma children is analyzed in detail and the restrains about those children's full integration to the process of education are examined. When Roma children start school they find themselves in a totally different world in terms of life and society. Teachers expect Roma children to be aware of the school rules and to act accordingly. However, in most of the cases Roma children do not meet the teachers' expectations and thus a conflict between the teacher and Roma children appears. Most of the times Roma children cannot afford course books and other resources which are necessary for classroom activities. Eventually, school life is boring and classroom activities are not interesting from the Roma children's perspective. Teachers rarely realize that they do not have enough knowledge about Roma children's life style. In a study conducted by 
Dominguez (1999) it is determined that teachers believe that schools are more effective in integrating Roma children to education. Teachers also state that schools should be helpful to Roma children in their adaptation; and schools also should be respectful to their culture. Moreover, teachers expres that Roma families, even though they stay indifferent towards school, and community organizations will play a major role in minority children's education. Most of the teachers also express that all of the families should participate in school activities only without any intervention.

In their study Trentin, Monaci, De Lume ve Zanon (2006) examined attitutes of teachers, who are inexperienced with integrated classrooms, towards Roma children. Results of the study reveal that it is quiet challenging to change prejudices even though there exists a direct communication. However, it is also determined that direct communication might provoke emotional reactions and change attitutes towards the Roma. Teachers state that they are concerned about the difficulties of employing an integrated education; and voluntariness towards the integrated education is in a medium level.

\section{What Roma mothers think about the kind of occupation they wish for their children:}

According to Fraser and Honneth (2003), the Roma is one of the social groups which is exposed to inequalities resulting from the society's class structure and the status order. On the one hand, the Roma can be defined as a group which is composed of "unqualified" workers who can mostly do manual jobs and work for very low wages, or as an underclass that is constantly kept away from jobs which would provide them with constant and proper income (an underclass which is considered even not worthy of being exploited); on the other hand, they are a sociocultural group which is usually looked down on in the dominant culture. In other words, the Roma is one of the groups which is both culturally and socioeconomically oppressed. Moreover, both of the areas of discrimination and unjustice reinforce each other, and it is not possible to say that one of the unjustices is a result of the other (Bayraktar Akkaya, 2011). A study by Koptekin (2013) lists the jobs that the Roma children want to have as follows: teacher, policeman, soldier, doctor, nurse. The reason why they want to be teachers might be the fact that all of the children interviewsed are indeed students and their teachers are the ones whom they know the best. When we consider the fact that in the environment these children grow up, many adults spend some time of their lives in prion, it would not be wrong to claim that the professions the children aim for is shaped by their own experiences. It is seen that the professions they mention either focus more on professions related to punishment (like policeman) or professions related to the issues of recovering, rehabilating, curing, shaping or guiding (such as doctor, nurse or teacher). It is considered that there is a relationship between the violence as well as the parent profiles these children articulated and the recovery-punishment separation revealed in their ideal job statements. 16 Roma mother participants state that they primarily want their children to be a "Prosecutor" or a "Lawyer". The reason why they want these occupations for their children might be because they commit crimes and are caught by the police; and when they go to court, the judge becomes the most powerful person over their lives. When they are asked about the reason why they choose these occupations, they first do not want to answer. However, when they are asked questions about tendency towards crime, it was understood that at least one person from each family was sent to prison or is still in prison. A Roma mother, whose husband is in jail, explains the reason why she wants her child to be a prosecutor as follows:

"If my child becomes a prosecutor, he can save his father from jail. (5)"

"I want my child to be a lawyer, because he should be aware of his own rights. (11)"

Roma mothers secondly prefer their children to be a doctor, a nurse or a teacher. 10 of the mothers state that they want their children to be a "Doctor", 4 of them want their children to be a "Teacher"; and 1 one of them want her children to be a "Nurse". Their reason for these pereferences/choices 
is their own health problems. The reason why one of the mothers prefer her child to be a teacher is as follows:

"When my child go to school, get educated and become a teacher, other children in the neighborhood will admire her and go to school as well. No one in this neighborhood has gone to school and has have an occupation. If one or two children go to school, others would follow and want to get educated. That's why I want my daughter to become a teacher and a role model for other children. (23)".

Another participant mother states that her daughter should better be doctor:

"I want my daughter to become a doctor, because we don't know how to read and write; and when we get ill it becomes more difficult for us to go to a hospital. If my daughter becomes a doctor, she can take good care of us, make us better. (1)".

5. What Roma mothers think about the activities for spending quality time with their children during daytime:

19 of the Roma mothers state that "They meet their children's fundamental needs", 5 of them state that "They watch TV with their children", and 3 of them express that "They do housework together". When Roma mothers are asked what else they do with their children, they express that their children stay outside and play games during the day and they need to do housework at home; thus they cannot spend so much time with their children. Moreover, 21 of the mothers state that even though they do not work regularly, when they find an opportunity they do jobs like selling tissues, daily housekeeping and street trading; therefore they need to leave home during the day. They also state that when they go to work some of their relatives or some family members take care of their children, and fathers usually do not help them in raising children. It is understood from the Roma mothers' views that what they consider spending quality time with their children is meeting the childrens' basic physical needs. The studies state that it is very important that families spend quality time with their children (Çağdaş and Seçer, 2011). The quality of the time devoted is matters more than the quantity of time (Y1lmaz, 2007). It is not enough to be next to the child and meet his/her physical needs. What is more crucal is to spend time with the child by making eye contact, having conversation and participating in activities which will contribute to his/her development (MEB, 2013). The results obtained from the study reveal that the Roma mothers are insufficient in spending quality time with their children.

\section{B. Views of the Roma mothers regarding their children's tendency towards crime:}

1. Views of Roma mothers regarding their attitudes when their children commit crime:

Roma mothers stated that their children do not commit crime and that they are very well behaving. On the other hand, according to the data gathered from the Security Directorate, the crime rate in the district is high. This conflicting case is believed to result from distrustful attitudes of Roma mothers towards foreigners (researchers). When they are asked about what they do when their children commit crime, 30 of the Roma mothers said that "they beat their children", while 16 mothers stated that "they scold and yell at their children". 3 of the mothers said in addition to the aforementioned actions, "they complain to fathers about children's crime". Participant mothers stressed that they do not want their children to get involved in any crime; however, due to the environment they live in, they are aware that their children have tendency towards crime. It is seen that when their children commit crime, mothers usually try to avert them from crime by beating them and scolding them. When their actions fell short in preventing Roma children from committing crime, then they ask help from the fathers. The mothers whose husbands are in prison ask for help from other family elders who usually live very close. 
Nevertheless, since the living environment is pushing for crime, children participate in crime activities despite all the warnings they get. It can be said that why these children repeat committing crime is because of culture-specific problem-solving methods, parents' and children's lack of education as well as financial problems. Roma parents do not know how to approach their children and establish healthy communication with them when they commit crime (Kaplan, Işık Çalışkan, Gürbüz, Göktaş and Özdil, 2013; Karabacak, 2013; Kuğuoğlu, 2013). Since the subjects why children commit crime and the possible solutions cannot be resolved in the family through constructive talk, crime continues.

\section{Views of Roma mothers regarding the precautions they take in order to prevent their children's} committing crime:

While 17 of the mothers stated that "they can take steps to prevent their children from committing crime by talking to them", 13 mothers argued that "by scolding or bringing the case to the fathers" they can avert their children's perpetrating crime. Two of the Roma mothers state their views about the ways in which they take measures so that their children do not commit crime as follows:

"No matter how much we talk to our children and try to keep them away from crime, other children in the neighborhood beguile them. We talk to our children, get angry with them, beat them, and complain to their fathers; however, they still commit crime. (2)"

"If my child commits crime, I talk to him/her. I explain him/her that what s/he did is wrong and will have consequences. Nevertheless, after some time, the children continue to perpetrate. (17)"

According to Karabacak (2013) and Kuğuoğlu (2013), the factors that push children toward crime are various. These factors can result from family, peer group, school, society's social and economic policies, education, health, welfare system, juvenile justice system, media, society or one's individual traits. What is at the core of these elements triggering juvenile delinquency is genetic, cultural, traditional, moral, individual, psychological or social characteristics. Family (as one of the most important instutions that raise a child) is the most influential institution in terms of teaching the basic values to children. It is the family that shapes a child's personality and socialization. Scientific studies show that while families shape their children, the mistakes they do (consciously or unconsciously) become the major factors that paves the way for juvenile delinquency. While family is the first source with regards to juvenile delinquency, other social institutions which have effects in shaping a child's personality and socialization also hold an important place. Moreover, studies also state that peer groups and mass media tools are also important factors that might affect a child negatively in terms of socialization and triggers a child's inclination towards crime.

Similar to other poor children's cases, the Roma children's poverty level increases due to having large families among other factors. In many cases, it is observed that Roma children (have to) work in the streets in order to contribute to the family economy. Moreover, Roma children have further disadvantages. Typically, Roma children start working at early ages, and they also get marry early. The Roma prefer to stay away from administrative regulations, and therefore, this causes the risk that the Roma children are not properly registered in records; they do not start school at the right time, and they cannot benefit from healthcare and other social services. Roma families do not have much experience regarding the advantages of formal education, and it is observed that they do not give enough attention to this matter. Except from entertainment sector, they do not have successful role models in other areas. Furthermore, their work conditions increase the risk for alcohol and drug addiction (UNICEF, 2012). The Roma people have difficulties accessing education and health benefits and work opportunities, and thus have unfavorable living conditions (Eren, 2008; Aşkın, 2011).

Children in the neighborhoods where Roma families inhabit are in the danger of working or begging in the streets and becoming drug addicts; these children are at the high risk of participating in 
crime or being a crime victim. When we talk about children at risk, we not only refer to children who commit crime but also to children who are likely to turn to crime (Aylar, 2006). The stigmatization of the Roma neighborhoods as the areas of crime also affects the Roma's participation in the city life. The Roma state that they cannot go to the city centers - for example, go to a shopping mall or to a restaurant-because when the word Roma is articulated then the words "thief" (Suntekin, 2008) and "sinister" come to people's mind. The stigmatized settlements of the Roma drift them apart from the cities and make them stuck in their own territories and, therefore, not allow them to actively take parts in the society (Akkan, Deniz and Ertan, 2011). According to Kaplan, Işık Çalışkan, Gürbüz, Göktaş and Özdil (2013), juvenile delinquency has been increasing both in Turkey and in many countries around the world. The character of a child, the environmental factors, social and living conditions are among the factors that push a child towards crime. According to the study results, there is a yearly increase in children's involvement in crime, and the girls are more victims of crime than boys. Therefore, it is suggested that the risk groups in children should be determined and the necessary precautions be taken from a multidisciplinary approach.

According to Lovrich, Thomas and Marshall (2013), juvenile delinquency is an issue that researchers in the field of crime and justice show increasingly more interest. The increasing number of juvenile delinquency both in Turkey and in the world is the main reason behind this growing attention. In our society, it is not possible to simply explain the juvenile delinquency with one reason, and determining the factors that pave the way for crime is a main challenge.

Şahinli (2013) analyzed the family factors that are influential in juvenile delinquency as well as the suggestions made to resolve these problems. The study results revealed that almost all of the children (participated in the study) who are convicted or imprisoned have the habit of running away from home. It is determined that more than $\% 70$ of the families has weak control over their children. The education level of the children's families as well as their socioeconomic statuses is very low. \% 87.1 of the mothers' education level is primary or below that, while $\% 69.7$ of the fathers have primary or below level of education. More than half of the children's families have members who commited crime before. Moreover, the study also shows that \%33 of the children come from broken families. As the studies reflect, there are various factors that push children towards crime.

\section{Result and Suggestions}

When we analyze the reasons why Roma mothers want to send their children to school, we see that the Roma mothers want their children to have an occupation, they do not want their children to be uneducated and suffer as they have had. When we look at the views of Roma mothers regarding which conditions they want their children to have education in case financial opportunity is provided, we see that they want to send their children to a boarding school or to a private school; they want their children to go to a school away from where they live, and they also want them to go to school by a school bus. When we look at what Roma mothers think about the kind of occupation they wish for their children, we see the results of the study reveal that most of the Roma mothers want their children primarily to become a judge, a prosecutor and a lawyer. As a second option they prefer their children to become a doctor, a teacher and a nurse. When we look at what Roma mothers think about the activities for spending quality time with their children during daytime, we see that they fulfill their children's fundamental needs, they watch TV with their children, and they do housework together.

As for Roma mothers' thoughts on their responses to their children's committing crime, mothers usually try to avert them from crime by beating them and scolding them. When their actions fell short in preventing Roma children from committing crime, then they ask help from the fathers. When it comes to the precautions that Roma mothers take to prevent their children from committing crime, the mothers state that they can avert their children from penetrating crime by talking to the children or scolding them or complaining to their fathers. 
It can be concluded that there exists a major resistance to children's education in the Roma culture; therefore lack of education and not having a profession/occupation lead the Roma children towards crime. Roma individuals believe that they won't be able to change their situation no matter how they try; and their pschological situation might be explained with Seligman's theory of learned helplessness.

Therefore, administrative authorities have to prepare special projects for the Roma children, and they also have to find/choose good examples of Roma people who got educated and have a profession. This method was employed on peasant children ten years after The Turkish republic was established, and those peasant children had become teachers, state officers and administrative staff. And this revealed that education might help people from countryside to change their social stratum. A similar project can be implemented in Konya for the Roma families as well. Conferences, seminars and workshops can be organized, and these events can focus on how the Roma's perspectives and life styles affect their children's getting quality education and continuing school. Possible solutions to the problem, for example, what can be done both on school, town/city Educational Directorates and Ministries levels and on local government levels can be explored in these organizations. Solutions can be sought by the professionals with regards to the following issues: school management and the competence of school administrators and teachers in terms of working with children under risk, when it comes to teaching-learning and psychological support services; the effects of the school staffs' perceptions of the Roma children upon these children's access to education, attendance and progression; the conditions at the schools and their competencies in developing policies and implementing them for different student potentials. Education systems which enable children to use their potentials more effectively and allow them to use their ethnic culture along side their potentials need to be created. If educational policies which are appropriate for the cultural structure in the region can be developed, then the children's relationship with the school can be strengthened and the families can be gained.

\section{References}

Akgün, S. (2004). Illköğretim sekizinci sınffta öğrenim görmekte olan roman çocukların bir üst ögrenime devam etmelerini etkileyen faktörler (Antalya Zeytinköy Örneği). Yayınlanmamış Yüksek Lisans Tezi. Konya: Selçuk Üniversitesi Sosyal Bilimler Enstitüsü.

Akkan, B. E., Deniz, M. B. ve Ertan, M. (2011). Sosyal dişlanmanın roman halleri. İstanbul: Punto Baskı Çözümleri.

Aspy, C. B., Oman, R. F., Vesely, S. K., McLeroy, K., Rodine, S., and Marshall, L. (2004). Adolescent violence: The protective effects of youth assets. Journal of Counseling and Development, 82, 269-277.

Aşkın, U. (2011). Küreselleşme sürecinde Türkiye'de yaşayan romanların sosyo-ekonomik durumları ve beklentileri: İzmir İli örneğinde bir alan araştırması. Yayınlanmamış Doktora Tezi. Ankara: Ankara Üniversitesi Sosyal Bilimler Enstitüsü.

Aylar, E. (2006). Gorki topluluğu üzerine bir araştırma. Eğitimde Kalite Yaklaşımları Dersi. Ankara: Ankara Üniversitesi Eğitim Bilimleri Enstitüsü.

Bayraktar Akkaya, Ö. (2011). Çingeneler: "Başka bir dünyanın insanları". Global Media Journal, 1(2), 121-136.

Bedmar, V. L. and Leon, N. T. (2012). Lifelong learning of gypsy women in Spain. Procedia - Social and Behavioral Sciences, 46, 3119-3123.

Cigez, A. S. and Lopez, R. G. (1999). Gypsy children's schooling and intercultural attitudes in Spain. European Journal of Intercultural Studies, 10 (2), 207-217.

Cozma,T., Cucos, C., and Momanu, M. (2000). The education of Roma children in Romania: description, difficulties, solutions. Intercultural Education, 11 (3), 281-288.

Çağdaş, A. ve Seçer, Z. (2011). Anne-baba eğitimi. Ankara: Eğiten Kitap. 
Dominguez, S. P. (1999). Teachers' attitudes about the integration of Roma: The case of Spain. Intercultural Education, 10 (2), 219-231.

Enache, R. (2012). Educational intervention for a group of socially disadvantaged pre-schoolers from Constanta, Romania. Procedia-Social and Behavioral Sciences, 46, 4995-4999.

Erdeniz, G. (2005). Risk altındaki çocuklar eğitim atölyesi-I. İstanbul. Retrieved on 11.10.2010, from http://erg.sabanciuniv.edu/sites/erg.sabanciuniv.edu/files/BETAMRapor.pdf

Eren, Z. C. (2008). Imagining and positioning gypsiness a case study of gypsy/roma from Izmir, Tepecik. Unpublished thesis. Ankara: Middle East Technical University. Retrived on 12.28.2013 from http://academos.ro/sites/default/files/biblio-docs/837/index_2_0.pdf (12.28.2013).

Fraser, N and Honneth, A. (2003). Redistribution or recognition?: A political-philosophical exchange. Translated by Joel Golb, James Ingram and Christiane Wilke. London: Verso.

Gökçen, S. ve Öney, S. (2008). "Türkiye'de Romanlar ve Milliyetçilik”, Ebru Uzpeder, Savel-ina Danova/Roussinova, Sevgi Özçelik ve Sinan Gökçen (Eds.). Biz Buradayız! Tür-kiye'de Romanlar, Ayrımcı Uygulamalar ve Hak Mücadelesi. İstanbul: Mart Matbaacılık.

Karabacak, N. (2013). "Türk Eğitim Sisteminde suç sorunu ve suçun psiko-sosyal boyutları". 5. Uluslararası Risk Altında ve Korunması Gereken Çocuklar Sempozyumu, Antalya: Bildiri Özet Kitab1.

Kaplan, B., Işık Çalışkan, Z., Gürbüz, D., Göktaş, N., ve Özdil, K. (2013). Nevşehir İl Merkezinde suça sürüklenen ve suç mağduru olan çocuklara genel bir bakış. 5. Uluslararası Risk Altında ve Korunması Gereken Çocuklar Sempozyumu, Antalya: Bildiri Özet Kitabı.

Koptekin, D. (2013). Roman çocukların kendi kimliklerini tanımlama biçimleri: İzmir Tepecik Örneği. Yayınlanmamış yüksek lisans tezi. İzmir: Dokuz Eylül Üniversitesi Eğitim Bilimleri Enstitüsü.

Kuğuoğlu, İ. (2013). "Suç işleyen çocukların algılamasına göre toplumdaki sosyal kurumların suça yönelmede etkililik düzeyi". 5. Uluslararası Risk Altında ve Korunması Gereken Çocuklar Sempozyumu, Antalya: Bildiri Özet Kitabı.

Kyuchukov, H. (2000). Transformative education for Roma (Gypsy) children: An insider's view. Intercultural Education, 11(3), 273-280.

Lovrich, N., Thomas, A., and Marshall, W. (2013). "Insights from the history of U.S. Efforts to legislate, adjudicate and enforce protections against child abuse". 5. Uluslararas1 Risk Altında ve Korunması Gereken Çocuklar Sempozyumu, Antalya: Bildiri Özet Kitabı.

McDonald, C. (1999). Roma in the Romanian Educational System: Barriers and leaps of faith. European Journal of Intercultural Studies, 10 (2), 183-200.

MEB, (2013). 0-36 Ay çocuklari için eğitim programi ile bütünleştirilmiş aile destek eğitim rehberi (Ebader), Eğitimci kitabi, Ankara.

Özdemir, S., Sezgin, F., Şirin, H., Karip, E. ve Erkan, S. (2010). İlköğretim okulu öğrencilerinin okul iklimine ilişkin algılarını yordayan değişkenlerin incelenmesi. Hacettepe Üniversitesi Ĕgitim Fakültesi Dergisi, 38, 213-224.

Özkan, A. R. (2013). Türkiye çingeneleri. Retrived on 05.27.2013 from http://www.turkiyecingeneleri.8m.com/

Smith, T. (1997). Recognising Difference: the Romani 'Gypsy' child socialization and education process. British Journal of Sociology of Education, 18 (2), 243-256.

Suntekin, C. (2008). Roman çocukların gözüyle ailelerin işlevselliği: Tarlabaşı Örneği. Yayınlanmamış yüksek lisans tezi. Ankara: Hacettepe Üniversitesi Sosyal Bilimler Enstitüsü.

Şahinli, K. (2013). "Familial factors affecting entrainment child crime". 5. Uluslararası Risk Altında ve Korunması Gereken Çocuklar Sempozyumu, Antalya: Bildiri Özet Kitabı.

Trentin, R., Monaci, M. G., De Lume, and Zanon, O. (2006). Scholastic integration of gypsies in Italy teachers' attitudes and experience. School Psychology International, 27 (1), 79-103.

Uğurlu, Ö. (2013). Dönüşen kentlerde Çingene olmak: İzmit örneği. Mülkiye Dergisi, 37 (1), 71-104. 
UNICEF, (2009). Retrieved on 11.10.2009, from http://www.unicef.org/turkey /pc/ge17.html

UNICEF, (2012). Kent ortamlarında Roman çocuklar. Retrieved on 07.12.2012, from http://www.unicef.org.tr/tr/content/detail/53/children-in-the-population.html

Yıldırım, A. ve Şimşek, H. (2006). Sosyal Bilimlerde Nitel Araştırma Yöntemleri. (Altıncı Baskı). Ankara: Seçkin Yayınevi.

Yılmaz, H. (2007). Sevgili Anne ve Babacığım, Lütfen Bu Kitabı Okur musunuz!. (27. Baskı). Konya: Çizgi Kitabevi.

http://www.konya.pol.tr/cocuk/72.htm\#_Toc123117042 (09.10.2009). 